\title{
Cronyism and Delaware Incorporation: An Examination on Excess Compensation
}

\author{
Qian Xie ${ }^{1}$ \\ ${ }^{1}$ School of Business and Management, East Stroudsburg University of Pennsylvania, East Stroudsburg, USA \\ Correspondence: Qian Xie, School of Business and Management, East Stroudsburg University of Pennsylvania, East \\ Stroudsburg, PA 18301, USA. Tel: 1-618-201-9300. E-mail: qxie@esu.edu
}

Received: August 25, 2013

Accepted: September 16, 2013

Online Published: October 9, 2013

doi:10.5430/afr.v2n4p60

URL: http://dx.doi.org/10.5430/afr.v2n4p60

\begin{abstract}
This paper investigates whether Delaware incorporation relates to cronyism by examining excess director and CEO compensation. I find that excess director compensation is significantly and positively related to excess CEO compensation in both Delaware and non-Delaware firms. However, excess CEO compensation in non-Delaware firms is negatively associated with firm performance. The result indicates that cronyism does exist in non-Delaware firms but not in Delaware firms. Therefore, Delaware incorporation does not favor managers at the expense of shareholders.
\end{abstract}

Keywords: CEO compensation, Director compensation, Excess compensation, Delaware incorporation, Firm performance

\section{Introduction}

The occurrence of many corporate scandals in recent years shows that the board may not act in the interests of the shareholders. To encourage directors to perform this crucial role for shareholders, financial incentives to directors become more necessary. Job complexity, amount of time, and increased risk of firm operation nowadays after the Sarbanes-Oxley Act justify the practice of paying directors high compensation. In addition, granting stock or option to directors would attract and retain qualified directors, and motivate them to monitor the management. However, critics insist that higher director compensation, especially in the forms of stock, option, or other types of incentives, would impair the independence of directors, making them lose their objectiveness and creating entrenched management. O'Reilly, Main, and Crystal (1988) find that CEOs can receive compensation increases by choosing outside directors who have higher compensation. Through the comparison of CEO compensation with outside director compensation, directors with higher levels of compensation are more likely to feel that CEOs are underpaid. Furthermore, inside directors and CEOs may agree to increase compensation for outside directors in exchange for increased compensation for management (Crystal, 1991; Lublin, 1991). These evidences show that director financial incentive is related to CEO compensation.

Corporations in the United States are governed by their state of incorporation. By selecting a state to be incorporated, a corporation selects a set of laws under which it must operate. Delaware is the winner of all states in the United States because the dominance of incorporation and reincorporation of publicly traded companies in the state of Delaware has remained stable over the last four decades (Subramanian, 2002). However, whether Delaware incorporation favors shareholders or managers is an ongoing debate. Jiraporn, Chintrakarn, and Davidson (2009) find that the boards of Delaware firms are relatively more independent and smaller than those of non-Delaware firms. Jiraporn and Gleason (2007) argue that earnings management occurs less in Delaware firms than in non-Delaware firms. CEOs with poor performance in Delaware are more likely to be terminated than those in other states (Jagannathan, Paul, \& Pritchard, 2007). These studies support that Delaware incorporation favors shareholders. Critics, however, suggests that state incorporation competition caters to the needs of managers (Cary, 1974). Bebchuk and Ferrell (2001) argue that state competition pushes states to give significant weight to managerial interests, because managers have the most influence on which state companies are incorporated in. In addition, compared with other states, Delaware has more restrictive takeover rules, which help managers maintain their jobs and private benefits. Finally, their study finds no robust and significant correlation between Delaware incorporation and high shareholder wealth.

Brick, Palmon, and Wald (2006) present the hypothesis of cronyism, in which a negative relationship exists between firm performance and excess compensation of the CEO and directors. The excess director compensation decreases 
independence of directors and therefore causes increased CEO compensation. My paper uses excess compensation to examine the relationship between Delaware incorporation and the existence of cronyism. If Delaware incorporation favors shareholders, cronyism does not exist in Delaware firms. In other words, the excess CEO compensation is expected to be positively related to firm performance in Delaware firms. If Delaware incorporation favors managers at the expense of shareholders, the excess CEO compensation is expected to be negatively related to firm performance in non-Delaware firms. I find that excess director compensation is significantly and positively related to CEO compensation in both Delaware and non-Delaware firms. However, excess CEO compensation in non-Delaware firms is negatively associated with firm performance. Therefore, Cronyism does exist in non-Delaware firms but not in Delaware firms. The finding indicates that Delaware incorporation does not favor managers at the expense of shareholders. The results have an implication for firms that have to choose what state to incorporate or reincorporate. Delaware incorporation sends a relatively positive signal to potential shareholders that the decision to incorporate in Delaware, rather than any of other states in the United States may be better.

The rest of this paper is organized as follows: Section 2 gives a brief literature review that helps develop hypotheses. Section 3 describes data sources, sample selection, variable definitions, and the methodologies. Section 4 discusses the empirical results and their implications in detail. Finally, Section 5 summarizes this study.

\section{Literature Review and Hypothesis}

\subsection{Director Compensation and Firm Performance}

The new rules for executive and director compensation by The Securities and Exchange Commission require that, after December 15, 2006, director compensation disclosures have the same format as that of executive compensation. The purpose of the new rules is to encourage shareholders and activist groups to review director compensation practices, which attracted less attention in the past (Rothenberg \& Blackman, 2007). The attention of director compensation increases according to an increasing number of shareholder lawsuits and rapidly increasing financial rewards for board membership. (Overton, 1990; Kesner \& Johnson, 1990)

One of recent changes in director compensation is double-digit growth in board total remuneration (Archer, 2005). Perry (2000) finds that in S\&P firms, the use of equity-based compensation for outside directors increased from $48 \%$ to $70 \%$ from 1992 to 1995. Proponents of higher director compensation argue that the complexity of the job, amount of time, and increase of risk of firm operation nowadays justify this practice. Granting stocks or options to directors may attract and retain qualified directors, and motivate the directors to monitor the management, therefore aligning interests of shareholders and directors and maximizing firm value (Overton, 1990; Maug, 1997). Given the growth rates of CEO pay in recent years, particularly in the form of stock options and other long-term incentives, Meyer and Richey (1991) argue that directors currently are being underpaid. They further state that, due to the increased amount of time directors must spend preparing for board meetings, it is necessary to increase board compensation. However, CEOs may use board compensation to co-opt board independence. Critics insist that higher director compensation, especially in the forms of stocks, options, or other incentives, may impair the independence of directors by making them lose their objectiveness and creating entrenched management.

If directors actually contribute to firm performance, compensation levels should be positively related to firm performance levels. Cordeiro, Veliyath, and Eramus (2000) show that outside director compensation is decided by firm performance in terms of stock returns, director efforts, outsiders' monitoring, referents such as CEO compensation, and control variables such as insider ownership and firm size. Cordeiro, Veliyath, and Neubaum (2005) also find that director stock compensation and firm performance have a significantly positive relationship.

\subsection{CEO compensation and firm performance}

Firm performance is a major determinant of CEO compensation (Jensen \& Murphy, 1990). High levels of compensation are effective incentives to retain and motivate CEOs to better act in the interests of shareholders. By linking pay to firm performance, powerful incentives are created. However, results from empirical studies on the relationship between CEO compensation and firm performance are mixed. Many studies show or cite a relationship between CEO compensation and firm performance (Milkovich \& Rabin, 1990; Finkelstein \& Hambrick, 1989), while others report no relationship (Leonard, 1990). The lack of conclusive evidence that executive pay is positively related to firm performance has led many critics to call for CEO compensation reform.

\subsection{Research Hypotheses}

The relationship between director compensation and CEO compensation has been examined by O'Reily et al. (1988). On one hand, outside directors previously receiving high levels of compensation may be likely to increase CEOs' compensation. On the other hand, CEOs are more likely to appoint highly paid outside directors in exchange for CEO 
compensation increases. Brick et al. (2006) examine the effectiveness of the board of directors by linking director compensation to CEO compensation. They hypothesize that "well-compensated directors may be less likely to 'rock' the boat." In other words, excess director compensation prompts weak monitoring. If excess compensation for both CEOs and directors is negatively related to firm performance, it is called "cronyism." The view of "race to the top" (Winter, 1977) on Delaware incorporation suggests that the market will discipline managers if they choose to incorporate in a state whose laws favor managers. Furthermore, firms in Delaware have a better corporate governance environment (Jiraporn \& Gleason, 2007; Jiraporn, Chintrakarn, \& Davidson, 2009; Jagannathan, Paul, \& Pritchard, 2007). Therefore, if Delaware firms favor shareholders, cronyism does not exist in these firms. If non-Delaware corporate law favors management at the expense of shareholders, it is thus expected that cronyism exists in non-Delaware firms. Managers in non-Delaware firms are more likely to be entrenched because directors in non-Delaware firms may not effectively monitor the management.

\section{Data}

The sample for this study is S\&P 1500 companies as listed in Compustat. The S\&P 1500 include the stocks of 500 large-cap corporations, 400 mid-cap corporations, and 600 small-cap corporations. CEO compensation and director compensation data are from ExecuComp. Data on board and CEO characteristics are collected from SEC proxy and 10-k. The information about the state of incorporation is gathered from the filing headers of proxy statements from EDGAR.

I exclude 232 financial companies and 81 utility companies from the list because there are extensive regulations for these two industries. Among the firms in the S\&P 1500 list, 12 firms that are incorporated in other countries are also excluded. In order to examine the incorporation effect, firms incorporated in the state of Delaware or other states less than 8 years from year 2005 are also excluded from the sample. The final sample includes 1,064 firms. There are 602 firms incorporated in the state of Delaware and 462 firms incorporated in other states. The sample period is from year 2002 to 2009.

Total director compensation is the total sum of the annual retainer, meeting fees multiplied by the number of meetings, the value of stocks, and the Black-Scholes value of options. Total CEO compensation includes salary, bonus, stocks, options, and other compensation. I adjust all the nominal compensation data using annual CPI data for the website of the United States Bureau of Labor: stats.bls.gov/cpihome.htm. ROA is the ratio of net income to total assets. Tobin's $\mathrm{Q}$ is the ratio of the market value of the firm to the book value of total assets. Market value of assets includes the book value of liabilities and preferred stock plus the market value of common stock. Duality is a dummy variable, which is equal to 1 if a CEO holds a title of chairman, otherwise 0 . CEO ownership is the percentage of a CEO's shareholding. CEO tenure is the number of years a CEO in the position. Number of meetings is the number of board meetings per year. Firm size is measured by total assets. Free cash is the ratio of free cash flow divided by sales. Risk is the standard deviation of the security market return. Investment opportunity is the ratio of R\&D expenditures scaled by sales. Expense is the ratio of selling, and administrative expenses to sales. Dividend is the ratio of dividend to assets. Leverage is a ratio of long-term debt to total assets.

\section{Results}

\subsection{Director and CEO Characteristics}

Table 1 summarizes director and CEO compensation and other characteristics. The average director compensation in Delaware firms is $\$ 167,890$, which is significantly higher than that in non-Delaware firms, $\$ 106,310$. Similarly, CEOs in Delaware firms, on average, receive $\$ 5,873,480$ of total compensation but CEOs in non-Delaware firms are paid $\$ 4,672,720$. This evidence shows that CEOs in Delaware firms receive more generous compensation than CEOs in non-Delaware firms do.

A higher CEO ownership prompts CEO entrenchment and therefore affects monitoring. CEO ownership is measured as the percentage of a CEO's shareholding. CEOs in Delaware firms have a higher shareholding than CEOs in non-Delaware firms.

Mallette and Fowler (1992) find that if an independent director is also a CEO of another firm, he may vote for a higher compensation plan for the CEO he should monitor. Duality is a dummy variable, which is equal to 1 if a CEO holds the title of chairman, or equal to 0 otherwise. The difference of duality between Delaware firms and non-Delaware firms is insignificant. 
Table 1. Summary statistics of director and CEO compensation and characteristics variables (Delaware and non-Delaware firms)

\begin{tabular}{llllll}
\hline & Delaware & \multicolumn{5}{l}{ non-Delaware } \\
\hline & Mean & SD & Mean & SD & t-statistic \\
\hline Total director comp (\$thousand) & 167.89 & 129.75 & 106.31 & 92.49 & $4.091^{* * *}$ \\
Total CEO comp (\$thousand) & 5873.48 & 159.47 & 4672.72 & 172.62 & $5.020^{* * *}$ \\
CEO ownership & 0.012 & 0.036 & 0.023 & 0.066 & $-6.635^{* * *}$ \\
CEO tenure & 8.27 & 7.22 & 8.94 & 7.80 & $2.608^{* * *}$ \\
Number of meetings & 8.06 & 3.50 & 7.53 & 3.02 & $2.531^{* * *}$ \\
Duality & 0.55 & 0.62 & 0.59 & 0.49 & -0.937 \\
\hline
\end{tabular}

*** denotes significance level of $1 \%$.

The longer a CEO's tenure is, the more likely the CEO has a closer relationship with the directors and has more knowledge about the firm. The CEO, therefore, may have more compensation. CEO tenure is measured as the number of years a CEO has been in the position. CEOs in Delaware firms have a shorter tenure of 8.27 years than 8.94 years in non-Delaware firms.

Finally, boards in Delaware hold an average of 8.06 meetings per year and boards in non-Delaware firms have 7.53 meetings per year. Boards in Delaware firms, on average, hold more meetings a year than those in non-Delaware firms.

\subsection{Correlations}

In Table 2, total director compensation is positively and significantly correlated to total CEO compensation. Total CEO compensation is positively and significantly correlated to CEO ownership, CEO tenure, the number of board meetings, and market value.

Table 2. Correlation Matrix

\begin{tabular}{llllllll}
\hline & $\begin{array}{l}\text { Director } \\
\text { comp }\end{array}$ & $\begin{array}{l}\text { CEO } \\
\text { comp }\end{array}$ & $\begin{array}{l}\text { CEO } \\
\text { ownership }\end{array}$ & Duality & $\begin{array}{l}\text { CEO } \\
\text { tenure }\end{array}$ & $\begin{array}{l}\text { No. of } \\
\text { meeting }\end{array}$ & $\begin{array}{l}\text { Market } \\
\text { value }\end{array}$ \\
\hline Director comp & 1 & & & & & & \\
CEO comp & $0.263^{* * *}$ & 1 & & & & & \\
CEO ownership & $-0.049^{* * *}$ & $0.109^{* * *}$ & 1 & & & & \\
Duality & 0.035 & $0.052^{* * *}$ & $0.039^{* * *}$ & 1 & & & \\
CEO tenure & -0.010 & $0.002^{* * *}$ & $0.228^{* * *}$ & 0.037 & 1 & & \\
No. of meeting & $0.132^{* * *}$ & $0.085^{* * *}$ & $-0.099^{* * *}$ & 0.12 & $-0.094^{* * *}$ & 1 & \\
Market value & -0.001 & $0.269^{* * *}$ & $-0.064^{* * *}$ & 0.193 & $-0.044^{* * *}$ & $0.053^{* * *}$ & 1 \\
\hline
\end{tabular}

*** denotes significance level of $1 \%$.

\subsection{Regression Analysis and Results}

Cronyism is tested in three steps. First, CEO compensation and director compensation are regressed on control variables, Duality, CEO ownership, CEO tenure, No. of meetings, Firm size, Free cash, Risk, Investment opportunity, Expense, Dividend, Leverage, Tobin's Q, and ROA. Excess CEO compensation and excess director compensation are the residuals of the regressions.

Total Director Compensation $=\alpha_{0}+\alpha_{1}$ Duality $+\alpha_{2}$ CEO ownership $+\alpha_{3}$ CEO tenure $+\alpha_{4}$ No. of meetings $+\alpha_{5}$ Firm size $+\alpha_{6}$ Free cash $+\alpha_{7}$ Risk $+\alpha_{8}$ Invest. Opp. $+\alpha_{9}$ Expense $+\alpha_{10}$ Dividend $+\alpha_{11}$ Leverage $+\alpha_{12}$ Tobin's $Q+\alpha_{13} R O A+$ year dummies

Total CEO Compensation $=\alpha_{0}+\alpha_{1}$ Duality $+\alpha_{2}$ CEO ownership $+\alpha_{3}$ CEO tenure $+\alpha_{4}$ No. of meetings $+\alpha_{5}$ Firm size + $\alpha_{6}$ Free cash $+\alpha_{7}$ Risk $+\alpha_{8}$ Invest. Opp $+\alpha_{9}$ Expense $+\alpha_{10}$ Dividend $+\alpha_{11}$ Leverage $+\alpha_{12}$ Tobin's $Q+\alpha_{13}$ ROA + year dummies

Second, the excess director compensation, Excess $s_{\text {Director Compensation, }}$ is included in the regressions where the dependent variables are CEO compensation to find if excess director and CEO compensation are positively correlated to each other. 
Total CEO Compensation $=\alpha_{0}+\alpha_{1}$ Excess $_{\text {Director Compensation }}+\alpha_{2}$ Duality $+\alpha_{3}$ CEO ownership $+\alpha_{4}$ CEO tenure $+\alpha_{5}$ No. of meetings $+\alpha_{6}$ Firm size $+\alpha_{7}$ Free cash $+\alpha_{8}$ Risk $+\alpha_{9}$ Invest. Opp. $+\alpha_{10}$ Expense $+\alpha_{11}$ Dividend $+\alpha_{12}$ Leverage $+\alpha_{13}$ Tobin's $Q+\alpha_{14} R O A+$ year dummies

Finally, if excess CEO compensation is positively related to firm performance measured by the change of market value, excess CEO compensation adds value for shareholders. Otherwise, it does not.

Change of Market Value $=\alpha_{0}+\alpha_{1}$ Excess $_{\text {CEO Compensation }}+\alpha_{2}$ Duality $+\alpha_{3}$ CEO ownership $+\alpha_{4}$ CEO tenure $+\alpha_{5}$ No. of meetings $+\alpha_{6}$ Firm size $+\alpha_{7}$ Free cash $+\alpha_{8}$ Risk $+\alpha_{9}$ Invest. Opp. $+\alpha_{10}$ Expense $+\alpha_{11}$ Dividend $+\alpha_{12}$ Leverage $+\alpha_{13}$ Tobin's $Q+\alpha_{14} R O A+$ year dummies

4.3.1 Director and CEO Compensation

Table 3. Director compensation and CEO compensation regressions (to get excess compensation)

\begin{tabular}{|c|c|c|c|c|}
\hline & Delaware & Delaware & Non-Delaware & Non-Delaware \\
\hline & $\begin{array}{l}\text { Total director } \\
\text { compensation }\end{array}$ & $\begin{array}{l}\text { Total CEO } \\
\text { compensation }\end{array}$ & $\begin{array}{l}\text { Total director } \\
\text { compensation }\end{array}$ & $\begin{array}{l}\text { Total CEO } \\
\text { compensation }\end{array}$ \\
\hline Constant & $2.676 * * *(13.430)$ & $4.385 * * *(24.800)$ & $3.030 * * *(12.329)$ & $5.074 * * *(20.008)$ \\
\hline Duality & $-0.047 *(-1.755)$ & $0.053 * *(2.489)$ & $-0.104 * * *(-2.723)$ & $0.097 * * *(2.789)$ \\
\hline CEO ownership & $0.007(0.260)$ & $0.181 * * *(7.497)$ & $0.013(0.343)$ & $0.027 * * *(3.576)$ \\
\hline CEO tenure & $-0.031(-1.076)$ & $0.007(0.282)$ & $-0.063(-1.313)$ & $-0.121 * * *(-3.323)$ \\
\hline No. of meetings & $0.114 * * *(4.229)$ & $-0.004(-0.190)$ & $0.213 * * *(5.634)$ & $0.158 * * *(4.604)$ \\
\hline Firm size & $0.242 * * *(8.305)$ & $0.676^{* * *}(29.388)$ & $0.136 * * *(3.449)$ & $0.383 * * *(10.668)$ \\
\hline Free cash & $-0.127^{*}(-1.900)$ & $-0.155 * * *(-2.921)$ & $-0.122(-1.371)$ & $-0.003(-0.031)$ \\
\hline Risk & $0.102 * *(3.521)$ & $0.044 *(1.935)$ & $0.037(0.944)$ & $0.001(0.031)$ \\
\hline Invest. Opp. & $0.204 * * *(5.157)$ & $0.004(0.116)$ & $0.231 * * *(3.414)$ & $-0.037(-0.605)$ \\
\hline Expense & $0.090 * *(2.310)$ & $0.077 * *(2.456)$ & $0.029(0.439)$ & $0.045(0.749)$ \\
\hline Dividend & $-0.218 * * *(-7.583)$ & $-0.043 *(-1.912)$ & $0.007(0.206)$ & $-0.016(-0.478)$ \\
\hline Leverage & $-0.091 * * *(-3.392)$ & $-0.072 * * *(-3.445)$ & $-0.041(-1.015)$ & $0.113 * * *(3.060)$ \\
\hline Tobin's Q & $0.340 * * *(11.655)$ & $0.169 * * *(7.497)$ & $0.108 * *(2.497)$ & $0.186^{* * *}(4.707)$ \\
\hline ROA & $0.201 * * *(2.909)$ & $0.220 * * *(4.006)$ & $0.168 *(1.761)$ & $0.112(1.289)$ \\
\hline$F$-statistics & $41.980 * * *$ & $97.635 * * *$ & $10.513 * * *$ & $22.691 * * *$ \\
\hline Adjusted $R$ square & $34.1 \%$ & $51.3 \%$ & $16.0 \%$ & $31.7 \%$ \\
\hline
\end{tabular}

Results of year dummies are not shown in the table. $* * *, * *$, and $*$ denote significance level of $1 \%, 5 \%$, and $10 \%$. T-statistics are in parentheses

Table 3 presents the parameter estimates of director compensation and CEO compensation. The purpose of the regressions in Table 3 is to find excess director and CEO compensation and the determinants of CEO compensation. The first two columns provide the estimates of director and CEO compensation for Delaware firms. The third and fourth columns report the estimates of director and CEO compensation for non-Delaware firms. In column 1, the estimated coefficient of duality is -0.047 and significant at $10 \%$. If a Delaware CEO is also a chair, directors in his or her firm may have less total compensation. This result is similar for non-Delaware firms $(-0.104)$ in column 3 . The estimated coefficient of the number of meetings is positive (0.114 and 0.213$)$ and significant in column 1 and column 3. The higher number of meetings represents more need for monitoring of CEOs by directors. Accordingly, directors may require more compensation for the increasing need for monitoring. Firm size is significantly and positively related to director compensation in both Delaware and non-Delaware firms. In Delaware firms, free cash ratio and director compensation have a significantly negative relationship. Directors receive more compensation if their firms have less free cash. The estimated coefficients of investment opportunity, Tobin's Q, and ROA are significantly positive in column 1 and column 3. The result shows that more growth options or better firm performance are associated with a higher level of director compensation. Smith and Watts (1992) also find a positive relationship between growth opportunity and executive compensation. The estimate coefficient of risk is 0.102 and significant in column 1 for Delaware firms but insignificant for non-Delaware firms. Delaware firms pay their directors more compensation when these firms have a higher risk. In addition, expense ratio is significantly and positively related to director compensation for Delaware firms but not for non-Delaware firms. Dividend ratio is significantly and negatively related to director compensation for Delaware firms but not for non-Delaware firms. The estimated coefficient of leverage is equal to -0.091 in column 1 for Delaware firms. Therefore, debts are negatively related to director compensation in Delaware firms. It also shows that debts may be a substitute for director 
compensation as a monitoring mechanism in Delaware firms. However, the estimated coefficient of leverage is insignificant for non-Delaware firms. Thus, debts may not be a substitute for director compensation as a monitoring mechanism in non-Delaware firms.

Table 3 also displays CEO compensation regressions in column 2 and column 4. In column 2, the estimated coefficient of duality is equal to 0.053 and significant at $5 \%$. If a CEO is also a chair, the CEO may have more total compensation. Duality makes a CEO more likely to be entrenched (Brick et al., 2006). This result applies to both Delaware firms and non-Delaware firms. The estimated coefficient of CEO ownership is equal to 0.181 and significant at $1 \%$ in column 2 for Delaware firms. The estimated coefficient of CEO ownership in column 4 for non-Delaware firms shows the same result. CEOs with a higher ownership have more total compensation in both Delaware and non-Delaware firms. CEO tenure has a negative relationship with director compensation in non-Delaware firms. The estimated coefficient of the number of meetings is equal to 0.158 and significant at $1 \%$ for non-Delaware firms but not for Delaware firms. If directors in non-Delaware firms hold more meetings a year, CEOs in these non-Delaware firms receive more compensation. Larger firms tend to pay more to their directors than smaller companies do. Free cash ratio and dividend ratio are negatively related to CEO compensation for Delaware firms. In addition, risk is positively related to CEO compensation for Delaware firms. The estimated coefficient of leverage is equal to -0.072 in column 2 for Delaware firms. Therefore, debts are negatively related to CEO compensation in Delaware firms. It shows that debts may be a monitoring mechanism for CEO compensation in Delaware. However, the estimated coefficient of leverage is insignificant for non-Delaware firms. Thus, debts may not play a role as a monitoring mechanism in non-Delaware firms.

\subsubsection{Excess Director Compensation and CEO compensation}

Regressions in Table 4 are to find whether excess director compensation, Excess Director Compensation $_{\text {, is }}$ is related to CEO compensation. The estimated coefficient of excess director compensation in the first regress is positive and significant for both Delaware (0.198) and non-Delaware firms $(0.283)$. The result shows that the more excess compensation directors are granted, the higher the CEO compensation, in both Delaware firms and non-Delaware firms. O'Reily et al. (1988) also find the positive relationship between CEO compensation and director compensation. Brick et al. (2006) argues that, if there is a relationship between excess director compensation and CEO compensation, "we do not interpret this relationship as causal, but rather as a conditional correlation between these variables." Table 5 tests whether cronyism exists in Delaware firms or non-Delaware firms by examining the relationship between excess CEO compensation and change of the market value.

Table 4. CEO total compensation and excess director compensation $\left(\right.$ Excess $\left._{\text {Director Compensation }}\right)$

\begin{tabular}{|c|c|c|}
\hline & $\begin{array}{c}\text { Delaware } \\
\text { Total CEO compensation }\end{array}$ & $\begin{array}{c}\text { Non-Delaware } \\
\text { Total CEO compensation }\end{array}$ \\
\hline Constant & $4.366 * * *(27.652)$ & $5.048 * * *(21.029)$ \\
\hline Excess $_{\text {Director Compensation }}$ & $0.198 * * *(9.994)$ & $0.283 * * *(9.142)$ \\
\hline Duality & $0.022(1.030)$ & $0.097 * * *(2.950)$ \\
\hline CEO ownership & $0.053(2.436)$ & $-0.026(-0.796)$ \\
\hline CEO tenure & $0.005(2.235)$ & $-0.125 * * *(-3.641)$ \\
\hline Number of meetings & $-0.011(-0.527)$ & $0.161 * * *(4.951)$ \\
\hline Firm size & $0.749 * * *(32.703)$ & $0.381 * * *(11.254)$ \\
\hline Free cash & $-0.107 * *(-2.042)$ & $-0.011(-0.137)$ \\
\hline Risk & $0.078 * * *(3.449)$ & $0.010(0.290)$ \\
\hline Invest. Opp. & $-0.001(-0.039)$ & $-0.041(-0.702)$ \\
\hline Expense & $0.111^{* * *}(3.626)$ & $0.053(0.917)$ \\
\hline Dividend & $-0.082 * * *(-3.621)$ & $-0.016(-0.513)$ \\
\hline Leverage & $-0.009(-0.411)$ & $0.113 * * *(3.231)$ \\
\hline Tobin's Q & $0.249 * * *(10.857)$ & $0.183 * * *(4.905)$ \\
\hline ROA & $0.192 * * *(3.543)$ & $0.120(1.469)$ \\
\hline$F$-statistics & $108.940 * * *$ & $29.733 * * *$ \\
\hline Adjusted $R$ square & $59.5 \%$ & $39.7 \%$ \\
\hline
\end{tabular}

Results of year dummies are not shown in the table. $* * * * *$, and $*$ denote significance level of $1 \%, 5 \%$, and $10 \%$. T-statistics are in parentheses. 


\subsubsection{Excess CEO Compensation and Firm Performance}

The regressions in Table 5 are to find whether excess CEO compensation, Excess ${ }_{C E O \text { Compensation, }}$ is related to firm performance. On one hand, if excess CEO compensation is positively and significantly related to firm performance measured by change of market value, it means the more excess compensation a CEO has, the better the firm performance, a result benefiting shareholders. On the other hand, if excess CEO compensation is negatively and significantly related to change of market value, the more excess compensation a CEO has, the worse the firm performance, a result indicating the existence of cronyism.

In the first column, the estimated coefficient of excess CEO compensation is positive but insignificant among Delaware firms. This result indicates that no cronyism exists in Delaware firms. Because the result is insignificant, I cannot conclude Delaware incorporation benefits shareholders. The proper way to describe the positive and insignificant estimated coefficient is that Delaware incorporation does not negatively affect shareholders' interests.

However, the estimated coefficient of excess CEO compensation in the second regression is negative $(-0.072)$ and significant at $10 \%$ in non-Delaware firms. The result shows that cronyism may exist in non-Delaware firms. When a firm decides not to incorporate in Delaware, the decision may not benefit shareholders.

Other findings include that among Delaware firms, investment opportunity, leverage, and Tobin's Q all positively impact change of market value but more expenses and issuing dividends negatively affect market value. Among non-Delaware firms, board meeting frequency, Tobin's Q, and ROA all positively impact change of market value but paying dividends to shareholders negatively affects market value.

Table 5. Firm performance and excess CEO compensation (Excess CEO Compensation $\left._{\text {. }}\right)$

\begin{tabular}{|c|c|c|}
\hline & & Non-Delaware \\
\hline & Change of market value & Change of market value \\
\hline Constant & $-0.863(-0.143)$ & $4.174(0.608)$ \\
\hline Excess $_{C E O \text { Compensation }}$ & $0.049(1.575)$ & $-0.072 *(-1.856)$ \\
\hline Duality & $0.017(0.533)$ & $-0.004(-0.102)$ \\
\hline CEO ownership & $0.005(0.170)$ & $0.018(0.473)$ \\
\hline CEO tenure & $0.028(0.852)$ & $0.003(0.078)$ \\
\hline Number of meetings & $0.011(0.365)$ & $0.104^{* * *}(2.721)$ \\
\hline Firm size & $0.055(1.626)$ & $-0.106^{* * *}(-2.662)$ \\
\hline Free cash & $0.103(1.334)$ & $-0.042(-0.465)$ \\
\hline Risk & $0.009(0.259)$ & $-0.020(-0.512)$ \\
\hline Invest. Opp. & $0.144 * * *(3.164)$ & $0.474 * * *(6.943)$ \\
\hline Expense & $-0.201 * * *(-4.499)$ & $-0.476^{* * *}(-7.043)$ \\
\hline Dividend & $-0.166^{* * *}(-5.368)$ & $-0.011(-0.307)$ \\
\hline Leverage & $0.088^{* * *}(2.827)$ & $0.059(1.442)$ \\
\hline Tobin's Q & $0.181 * * *(5.368)$ & $0.255^{* * *}(5.839)$ \\
\hline ROA & $0.095(1.198)$ & $0.196^{* *}(2.036)$ \\
\hline$F$-statistics & $11.245^{* * *}$ & $8.625^{* * *}$ \\
\hline Adjusted $R$ square & $13.0 \%$ & $15.0 \%$ \\
\hline
\end{tabular}

Results of year dummies are not shown in the table. $* * *, * *$, and $*$ denote significance level of $1 \%, 5 \%$, and $10 \%$. T-statistics are in parentheses.

\section{Conclusion}

The popularity of Delaware incorporation among publicly traded companies in the United States has been stable for four decades. The research on Delaware incorporation has not been able to conclude whether Delaware incorporation favors managers or shareholders. This paper examines the impact of Delaware incorporation on how effectively 
financial incentives to directors help them monitor CEOs and protect shareholders' interests. If directors do effectively monitor CEOs, excess director compensation should be positively related to CEO compensation and the excess CEO compensation is expected to be positively related to firm performance. In this case, cronyism does not exist. But if excess director compensation is positively related to CEO compensation but the excess CEO compensation is negatively related to firm, cronyism exists. I find evidence that excess director compensation is significantly and positively related to CEO compensation in both Delaware and non-Delaware firms. However, excess CEO compensation in non-Delaware firms is negatively associated with firm performance. Thus, cronyism may exist in non-Delaware firms but not in Delaware firms. The findings suggest that Delaware incorporation (firms that choose to be incorporated in Delaware rather than any of other states) does not favor managers at the expense of shareholders. Therefore, Delaware incorporation sends a positive signal about the quality of corporate governance to shareholders. The results may help firms in the United States make a decision on where to incorporate or reincorporate.

\section{References}

Archer, E. C. (2005). Director pay; taking the lead. Corporate Governance Advisor, 13(5), 1 - 8.

Bebchuk, L. \& Ferrell, A. (2001). A new approach to takeover law and regulatory competition. Virginia Law Review, 87(1), 111-164. http://dx.doi.org/10.2307/1073896

Brick, E., Palmon, O. \& Wald, J. (2006). CEO compensation, director compensation, and firm performance: evidence of Cronyism. Journal of Corporate Finance, 12(3), 403-423. http://dx.doi.org/10.1016/j.jcorpfin.2005.08.005

Cary, W. (1974). Federalism and corporate law: reflections upon Delaware. Yale Law Journal, 83(4), 663-705. http://dx.doi.org/10.2307/795524

Cordeiro, J., Veliyath, R. \& Erasmus, E. (2000). An empirical investigation of the determinants of outside director compensation. Corporate Governance: An International Review, 8(3), 268-279. http://dx.doi.org/10.1111/1467-8683.00204

Cordeiro, J.J., Veliyath, R. \& Neubaum, D. (2005). Incentives for monitors: Director stock-based compensation and firm performance. Journal of Applied Business Research, 21(2), 81 - 90.

Crystal, G. (1991), In search of excess: The overcompensation of American executives. New York: Norton.

Finkelstein, S. \& Hambrick, D. (1989). Chief executive compensation: A study of the intersection of markets and political processes. Strategic Management Journal, 10(2), 121-134. http://dx.doi.org/10.1002/smj.4250100203

Jagannathan, M., Paul, S. \& Pritchard, A.C. (2007). Does Delaware entrench management?" Working paper. Binghamton University and University of Michigan Law School.

Jensen, M. \& Murphy, K. (1990). Performance Pay and Top-management Incentives. The Journal of Political Economy, 98(2), 225-264. http://dx.doi.org/10.1086/261677

Jiraporn, P. \& Gleason, K. C. (2007). Delaware incorporation and earnings management: an empirical Analysis. Journal of Applied Finance, 17(1), 40-51.

Jiraporn, P., Chintrakarn, P. \& Davidson, W. (2009). Delaware Incorporation and the Board of Directors. Quarterly Journal of Finance \& Accounting, 48(3), 41-59.

Kesner, I. \& Johnson, R. (1990). An investigation of the relationship between board composition and stockholder suits. Strategic Management Journal, 11(4), 327-336. http://dx.doi.org/10.1002/smj.4250110408

Leonard, J. (1990). Executive pay and firm performance. Industrial and Labor Relations Review, 43, 135-295. http://dx.doi.org/10.2307/2523569

Lublin, J. (1991, April 22). While outside directors' pay increases, independence from managers may face. Wall Street Journal, pp. B1-B2.

Mallette, P. \& Fowler, K. (1992). Effects of board composition and stock ownership on the adoption of 'poison pills'. Academy of Management Journal, 35(5), 1010-1035. http://dx.doi.org/10.2307/256538

Maug, E. (1997). Boards of directors and capital structure. Journal of Corporate Finance, 3(2), 113-139. http://dx.doi.org/10.1016/S0929-1199(96)00010-7

Meyer, P. \& Richey, L. R. (1991). Recruiting and rewarding directors in the 1990s. Compensation \& Benefits Management, 6, 78-80. 
Milkovich, G. \& Rabin, B. (1990). Executive compensation and firm performance: Research questions and answers. Foulkes, F.K. Executive compensation: A strategic guide for the 1990s, Harvard Business School Press, Boston, pp. 81-97.

O'Reilly, C., Main, B \& Crystal, G. (1988). CEO compensation as tournament and social comparison: A tale of two theories. Administrative Science Quarterly, 33(2), 257-274. http://dx.doi.org/10.2307/2393058

Overton, B. (1990). Remuneration of outside directors. Foulkes, F.K. Executive compensation: A strategic guide for the 1990s, Harvard Business School Press, Boston, pp. 383-398.

Perry, T. (2000). Incentive compensation for outside directors and CEO turnover. Working paper. Arizona State University.

Rothenberg, L. S. \& Blackman, A. L. (2007). Executive compensation: scaling back current disclosure of compensation decisions. Bloomberg Corporate Law Journal, 2(2), 131-140.

Smith, C. W. \& Watts, R. L. (1992). The investment opportunity set and corporate financing, dividend and compensation policies. Journal of Financial Economics, 32(3), 263-292. http://dx.doi.org/10.1016/0304-405X(92)90029-W

Subramanian, G. (2002). The influence of antitakeover statutes on incorporation choice: evidence on the "race" debate and antitakeover overreaching. University of Pennsylvania Law Review, 150(6), 1795-1873. http://dx.doi.org/10.2307/3312981

Winter, R. K. (1977). State law, shareholder protection, and the theory of the corporation. Journal of Legal Studies, 6(2), 251-292. http://dx.doi.org/10.1086/467572 